\title{
System Management Software for Emergency Call
}

\author{
Gisele TORRENTEE ${ }^{\mathrm{a}, 1}$, Jander Menezes CAVALCANTI ${ }^{\mathrm{a}}$, Laila Melissa de Castro \\ Pinheiro BARBOSA a , Elielza Guerreiro MENEZES ${ }^{\text {a }}$, Camila SANTANA ${ }^{\mathrm{a}}$, \\ Thiago Queiroz de SOUZA ${ }^{\mathrm{a}}$, Leon MANICKCHAND Junior ${ }^{\mathrm{a}}$, Felipe MOTA ${ }^{\mathrm{a}}$, \\ Fernanda Costa PIMENTEL ${ }^{\mathrm{a}}$ and Geferson Oliveira da SILVA ${ }^{\mathrm{a}}$ \\ a Amazon State University, Brazil
}

\begin{abstract}
Present the experience of the development of a system as an effective communication strategy between the user/requester and the mobile prehospital care service. Approach: It is a methodological study, fragmented into five stages, developed by health and technology professionals and students. Result: The five stages were followed to reach the final product. Conclusion: The app is groundbreaking and contributes to the safe and efficient communication with healthcare professionals and users.
\end{abstract}

Keywords. Emergency Medical Services, information technology, informatics in nursing, technology in health, mobile applications

\section{Introduction}

The use of communication and information technology is a reality in health service, with tools like mobile internet, touchscreen displays, wireless networks, smartphones, and others, enables intuitive and instructive handling [1]. The mobile pre-hospital care service in Brazil works through the public health system that aims to assist the victim with sudden clinical, traumatic, obstetric, gynecological, pediatric and psychiatric injuries [2]. The literature report that the adoption of an effective and safe communication strategy between patients, health professionals and family members contribute to the patient's involvement in their own safety [3]. From that, this poster aims to present the system development as an effective communication strategy between the user/requester and the mobile pre-hospital care service.

\section{Approach}

It is a methodological study based on the consolidated software engineering five-stage life cycle model: analysis (identification of user's needs); design (detailing of goals, deadlines and assignments); development (programming, testing, corrections and documentation of the software); implementation (in the usability environment) and maintenance (adjustments and upgrades of the system), carried out in the period from

\footnotetext{
${ }^{1}$ Corresponding Author, Gisele Torrente, Nursing Department, School of Health Sciences, Amazon State University (UEA), Manaus-Amazon, Brazil; E-mail: gtorrente@ues.edu.br.
} 
2019 to 2021. The team was composed of health professionals (medicine and nursing) and Technology (Computer Engineering, Design and Information System), in addition to the participation of undergraduate and graduate academics from both areas. The app's home was based on the "three-click rule" to enter information about the victim, georeferencing call location (Google Maps), image uploads, health team chat and ambulance tracking in real time.

\section{Results}

The first stage for the development of the system was to conduct a survey to determine the user requirements. Five user profiles were identified: doctor, nurse, nursing technician, first responder driver and user requester, to then create stories to compose the backlog. The project used the Agile Scrum methodology for the management and organization of the project, where each month the project members could present their activities in the form of a report according to the goals and objectives stipulated. The prototype screens of the system was developed in Figma software, respecting the stories of users, covering their needs, and finally validated in stages according to development by the health team. Lastly, the implementation and maintenance through usability tests and other specifics was entrusted to software development professionals.

\section{Conclusions}

The app is groundbreaking in that it will be solve the lack of pre-hospital care service in Brazil. It allows people with special hearing and speech needs to trigger the emergency service and contributes to effective and safe communication between the user and the healthcare professionals.

\section{References}

[1] Toma TS, Pereira T da V, Vanni T, Barreto JO. Avaliação de Tecnologias de Saúde \& Políticas Informadas por Evidências Avaliação de Tecnologias Informadas por Evidências. São Paulo: Instituto de Saúde; 2017. 456 p.

[2] Saúde BM da. Política Nacional de Atenção às Urgências. In: Política Nacional de Atenção as Urgências [Internet]. 1a ed. Brasília: Editora MS; 2003. p. 228. Available from: http://portal.mec.gov.br/cne/ arquivos/pdf/CES03.pdf

[3] Silva TD, Lúcia A, Bezerra Q, Tanferri T, Paranaguá DB, Teixeira CC. O envolvimento do paciente na segurança do cuidado: Revisão integrativa. Rev Eletrônica Enferm. 2016;(1):1-12.

[4] Couto D, Barra C, Maria S et al. Methods for developing mobile apps in health: An integrative review of the literature. Texto Context - Enferm. 2017;26(4):1-12. 